\title{
Hak Masyarakat Adat atas Sumber Daya Alam: antara Doktrin Pembangunan dan Hukum Hak Asasi Manusia Internasional
}

\begin{abstract}
Mirza Satria Buana*
DOI: https://doi.org/10.22304/pjih.v4n2.a7

Abstrak

Tulisan ini bertujuan untuk menganalisa korelasi nilai-nilai Hak Asasi Manusia dalam lingkup internasional maupun nasional dengan doktrin pembangunan kontemporer dalam konteks perlindungan hak masyarakat adat atas sumber daya alam. Apakah kedua doktrin tersebut dapat berjalan beriringan dan bagaimana produk hukum nasional merespon norma-norma Hak Asasi Manusia, lalu apa saja celah doktrinal yang dapat menghambat pemberdayaan masyarakat adat dan pemenuhan hak konstitutional mereka. Setidaknya terdapat tiga isu masyarakat adat yang dibahas dengan memakai perspektif normatif-doktrinal dari hukum Hak Asasi Manusia Internasional, yaitu: hak kepemilikan kolektif; hak untuk berpartisipasi; dan hak mengelola sumber daya alam. Ketiga isu ini juga dipakai sebagai parameter dalam menilai derajat perlindungan hak tersebut di Indonesia. Dalam ranah perundang-undangan, pemerintah perlu segera melakukan revisi terhadap Undang-Undang Nomor 41 Tahun 1999 tentang Kehutanan, sebagai ikhtiar untuk mentransformasi nilai-nilai reformis dalam Putusan Mahkaman Konstitusi Nomor 35/PUU-X/2012. Diperlukan pula adanya UndangUndang Perlindungan Hak Masyarakat Adat, yang diposisikan sebagai tandem UndangUndang Desa dalam ranah desentralisasi, dan untuk melengkapi Undang-Undang sektoral Sumber Daya Alam. Undang-undang tersebut diharapkan dapat mengambil substansi Konvensi ILO 169 Tahun 1989 tentang Indigenous and Tribal Peoples dan juga substansi hak atas pembangunan dalam The Declaration on the Right to Development.
\end{abstract}

Kata kunci: hak masyarakat adat, hukum HAM internasional, hukum HAM nasional, pembangunan, sumber daya alam.

\section{Rights of Indigenous Peoples on Their Natural Resources: Analysis of Development Doctrine and International Human Rights Law}

\begin{abstract}
This paper analyzes human rights' values both in international and national levels with a contemporary development doctrine, particularly with regard to the legal protection of indigenous peoples on their natural resources. This paper aims to answer several questions, as follows: do human rights and development doctrine compatible each other, how does national law respond to human rights' norms, and what are doctrinal gaps that could hinder indigenous peoples to obtain their constitutional rights? This paper examines three crucial issues regarding to indigenous peoples' rights on International human rights law: right of collective ownership, right to participate in development and right of self-determination on

PADJADJARAN Jurnal IImu Hukum Volume 4 Nomor 2 Tahun 2017 [ISSN 2460-1543] [e-ISSN 2442-9325]

* Dosen Fakultas Hukum Universitas Lambung Mangkurat, Jl. Brigjen H. Hasan Basri, Kayutangi, Banjarmasin, mirzabjm@yahoo.com/mirza.buana@unlam.ac.id, S.H. (Universitas Lambung Mangkurat), M.H. (Universitas Islam Indonesia), Ph.D. (University of Queensland).
\end{abstract}


their natural resources. These three issues are also used as parameter to assess the protection of indigenous peoples' rights on their natural resources in Indonesia. This paper concludes that in legislation, the government should holistically revise Law on Forestry in order to transform arguments of Constitutional Court Decision Number 35/PUU-X/2012. In regulation concerning human rights, the government should stipulate Law on the Protection of Indigenous Peoples, which aims to strengthen the implementation of Law on Village in decentralization setting. The Law should adopt several important norms on ILO Convention regarding Indigenous and Tribal Peoples in Independent Countries 1989.

Keywords: the rights of indigenous peoples, international human rights law, national human rights law, development, natural resources.

\section{A. Pendahuluan}

Sebagai negara yang kaya akan hasil alam, Indonesia dalam pengelolaan sumber daya alam (SDA) dirasa masih kesulitan untuk mendistribusikan keadilan bagi masyarakat luas pada umumnya dan masyarakat lokal (adat) pada khususnya. Padahal secara filosofis-normatif, Pancasila sebagai dasar negara terutama sila kelima telah mensyaratkan "keadilan sosial bagi seluruh rakyat Indonesia". Dalam spektrum yang lebih spesifik, masyarakat adat sebagai pengampu hak kerap dinafikan eksistensi dan perannya sebagai kapital sosial dalam proyek 'pembangunan'.

Sepanjang pengalaman sejarah Indonesia dalam hal pengakuan hak-hak masyarakat adat, pemerintah pasca kemerdekaan di bawah pimpinan Soekarno (Orde Lama) dan Soeharto (Orde Baru) memiliki arah pemikiran yang cenderung menekankan pada politik persatuan yang bercorak unifikasi dan menganggap konsep masyarakat adat sebagai residu era kolonial yang berpotensi memecah belah rakyat Indonesia. Pemerintah beranggapan bahwa seluruh rakyat Indonesia (terkecuali keturunan Tionghoa) adalah masyarakat asli (pribumi) Indonesia. ${ }^{1}$ Politik uniformitas-simplistik ini juga diterapkan oleh negara tetangga, misalnya Filipina pada masa pemerintahan Presiden Ferdinand Marcos. ${ }^{2}$

Dalam nuansa kebatinan kenegaraan yang uniformitas terutama di era Orde Baru yang memuja program pembangunan ekstraktif-ekspansif tersebut, masyarakat adat, alih-alih dihargai dan diakui eksistensinya, mereka malah kerap dianggap sebagai penghalang bagi pembangunan nasional yang bercorak ekstraktifekspansif tersebut. ${ }^{3}$ Program-program pembangunan yang telah men-diskredit-kan

1 Christopher R. Duncan, "Mixed Outcomes, The Impact of Regional Autonomy and Decentralization on Indigenous Ethnic Minorities in Indonesia", Development and Change, Volume 38, Issue 4, 2007, hlm. 714.

2 Joan Carling, "Cordirella Peoples Alliances", UN Working Group on Indigenous Population, Jenewa, Swiss, 27 Juli 2001, hlm. 1.

3 Alexandra Xanthaki, "Land Rights of Indigenous Peoples in South-East Asia", Melbourne Journal of International Law, Volume 5, 2003, hlm. 468. 
masyarakat adat sejatinya ditopang oleh bangunan logika peraturan perundangundangan, misalnya Undang-Undang Nomor 5 Tahun 1967 tentang Kehutanan (UU Kehutanan 1967) yang menyatakan bahwa: "komunitas lokal tidak bisa/tidak boleh menggangu tujuan-tujuan yang dimaksud dalam undang-undang ini (implementasi program pembangunan)". ${ }^{4}$ Hal tersebut adalah sebuah bukti bahwa pranata hukum negara turut serta melakukan diskriminasi dengan memihak pada proyek 'pembangunan'. Perundang-undangan semata menjadi alas legalitas (justifikasi) terhadap praktik-praktik diskriminatif terhadap masyarakat adat.

Pada era tahun 1980-an, menurut Fay dan Sirait, telah terjadi pengambil-alihan lahan besar-besaran oleh pemerintah, di mana lebih dari $75 \%$ lahan hutan dikonversi menjadi 'hutan negara'. ${ }^{5}$ Di masa Orde Baru, konsep 'pembangunan' secara empiris telah mengalami penyempitan makna, dipandang semata sebagai terakumulasinya kuantitas kapital secara umum, namun abai terhadap proses pemberdayaan masyarakat dan pemerataan pembangunan.

Untuk merujuk pada definisi masyarakat adat, pemerintah Orde Baru memberi label 'komunitas adat terpencil', namun sayangnya pemberian nama tersebut alpa akan perlindungan hak-hak masyarakat adat. ${ }^{6}$ Alih-alih memberdayakan masyarakat tertinggal, pemerintah malah mengimplementasikan program akulturasi yang represif dan birokratis, lewat Undang-Undang Nomor 5 Tahun 1979 tentang Desa. Struktur desa yang sejatinya heterogen disama-ratakan menjadi 'desa'. Selain itu, kepala desa menjadi aparatur negara dengan diangkat sebagai Pegawai Negeri Sipil (PNS) dan bertanggung jawab kepada bupati/walikota dalam garis birokratis vertikal yang ketat. $^{7}$

Selain itu, pemerintah juga kerap menyelenggarakan program Pembinaan Kesejahteraan Sosial Komunitas Adat Terpencil (PKSKAT) yang bertujuan untuk melakukan percepatan (baca: pemaksaan) modernisasi kepada masyarakat adat. Alih-alih berdaya guna, program ini telah secara masif menghapus ciri komunalitas masyarakat adat. Program 'pembinaan' lainnya telah mengkonversi tanah ulayat menjadi hak milik privat, lewat program pendaftaran tanah. ${ }^{8}$

$4 \quad$ Pasal 17 Undang-Undang Nomor 5 Tahun 1967 tentang Kehutanan.

5 Chip Fay dan Martua Sirait, "Reforming the Reformists: Challenges to Government Forest Policies in PostSuharto Indonesia" dalam buku Which Way Forward? Forest, Peoples, and Policies in Indonesia, yang disusun oleh Colfer dan Resosudarmo, (et.al.), Institute of Southeast Asian Studies, 2001, hlm. 126. Lihat juga: Barbara Beckert, Christoph Dittrich, dan Soeryo Adiwibowo, "Contested Land: An Analysis of Multi-Layered Conflicts in Jambi Province, Sumatra, Indonesia", Austrian Journal of South-East Asian Studies, Volume 7, 2014, hlm. 84.

6 Christopher R. Duncan, "From Development to Empowerment: Changing Indonesian Government Policies toward Indigenous Minorities" dalam buku Civilizing the Margins: South-East Asia Government Policies for the Development of Minorities, yang disusun oleh Christopher R. Duncan, (et.al.), Cornell University Press, 2004, hlm. 105.

$7 \quad$ Undang-Undang Nomor 5 Tahun 1979 tentang Pemerintahan Desa.

8 Pasal 3 Peraturan Pemerintah Nomor 24 Tahun 1997 tentang Pendaftaran Tanah. 
Selepas keluar dari rezim sentralistik-otoritarian Orde Baru, Indonesia memasuki era reformasi yang menjunjung perlindungan HAM dan bersemangatkan desentralisasi. Menurut Bank Dunia, Indonesia dapat dikategorikan sebagai salah satu negara yang melakukan transisi kenegaraan paling ekstrem di dunia; dari negara paling tersentralisir di era Orde Baru, menjadi negara paling terdesentralisasi di era Reformasi. ${ }^{9}$

Walau desentralisasi juga memiliki beberapa friksi negatif, era reformasi yang desentralistik telah memberi ruang terhadap ikhtiar-ikhtiar untuk memberi keadilan bagi masyarakat adat yang termarginal secara bertahap. Titik awalnya adalah Putusan Mahkamah Konstitusi Nomor 35/PUU-XII/2012 Tahun 2012 terkait Pengujian Undang-Undang Nomor 41 Tahun 1999 tentang Kehutanan terhadap Undang-Undang Dasar 1945 (Putusan MK 35) yang secara signifikan merubah 'wajah' Undang-Undang Nomor 41 Tahun 1999 tentang Kehutanan (UU Kehutanan 1999); dengan memisahkan 'hutan adat' dalam kategori 'hutan negara'.

Putusan progresif ini kemudian diejawantahkan dalam bentuk produk legislasi lewat Undang-Undang Nomor 6 Tahun 2014 tentang Desa (UU Desa) yang memberi ruang afirmatif yang luas bagi keberadaan komunitas masyarakat adat dan desadesa adat. Titik puncaknya adalah dengan dikeluarkannya Peraturan Menteri Lingkungan Hidup dan Kehutanan Nomor 32 Tahun 2015 tentang Hutan Hak (Permen LHK 32/2015) yang telah memberi rambu-rambu normatif yang jelas untuk reformasi di ranah perlindungan hak-hak masyarakat adat. Hasilnya, delapan Surat Keputusan (SK) Menteri LHK dikeluarkan untuk Penetapan Hutan Adat, dan satu SK untuk addendum area konsesi di akhir tahun 2016.

Terlepas dari beberapa pencapaian di atas, kepentingan politik baik dari pemerintah daerah, perusahaan, maupun dari komunitas-komunitas masyarakat adat masih saling berkelindan dan berkompetisi memperebutkan kekuasaan, terutama di daerah-daerah yang kaya akan SDA. Norma hukum dan hak asasi manusia (HAM) tidak akan pernah dapat steril dari pertarungan kepentingankepentingan tersebut.

Tulisan ini mencoba mencari korelasi antara nilai-nilai HAM baik dalam lingkup hukum internasional maupun nasional dengan doktrin pembangunan kontemporer, apakah kedua doktrin tersebut dapat berjalan beriringan? Dan bagaimana produk hukum nasional merespon norma-norma HAM tersebut? Terutama yang terkait dengan isu sektoral SDA dan apa saja celah doktrinal yang dapat menghambat pemberdayaan masyarakat adat dan pemenuhan hak-hak konstitutional mereka. Untuk menjawab permasalahan di atas, tulisan ini disusun dalam beberapa sub-sub bahasan, yaitu: (1) perkembangan dari doktrin-doktrin HAM baik internasional dan nasional terkait isu pembangunan dan hak-hak

9 World Bank, “Decentralizing Indonesia: A Regional Public Expenditure Review”, Overview Report, 2003, hlm. 5. 
masyarakat adat; (2) respon pemerintah terhadap norma-norma HAM tersebut; dan sekaligus (3) deskripsi tentang celah doktrinal dari perlindungan masyarakat adat.

\section{B. Sejarah Singkat Hukum Hak Asasi Manusia Internasional}

Pasca Perang Dunia I dan II yang menorehkan luka pada kemanusiaan, masyarakat internasional mulai berbenah dengan mendirikan suatu organisasi multilateral bernama United Nations (UN) atau Perserikatan Bangsa-Bangsa (PBB). Esensi perjuangan PBB dalam isu HAM dan kemanusiaan dapat terbaca dalam Piagam PBB, sebagai berikut:

"The purpose of the UN included the development of friendly relations based on the principle of equal rights and self-determination, ${ }^{10}$ and the promotion and encouragement of respect to human rights and fundamental freedom for all without distinction as to race, sex, language or religions." 11

Pergerakan moril PBB di atas kemudian lebih dikongkritkan dengan dikeluarkannya Universal Declaration of Human Rights (UDHR) atau Deklarasi Universal tentang HAM. Dalam merespon praktik pembangunan pasca kolonialisme yang eksklusif dan nir-keadilan, UDHR memberikan gambaran idealisnya, sebagai berikut:

"By virtue of which every human person and all peoples are entitled to participate in, contribute to, and enjoy economic, social, cultural and political development, in which all human rights and fundamental freedom can be fully realized." 12

Sebagai sebuah pergerakan moril, HAM memiliki 'perangkat lunak' yang dapat diinternalisasi ke dalam sistem kenegaraan secara langsung lewat ratifikasi. Namun implementasi HAM tersebut kerap dilakukan secara bertahap, tergantung pada konteks sosial-politik negara-negara tersebut. ${ }^{13}$ Terutama dalam konteks negaranegara berkembang dan dalam transisi demokrasi, nilai-nilai HAM harus diinternalisasi secara bertahap namun berkesinambungan.

Perkembangan HAM dapat dibagi dalam tiga generasi: hak liberal; hak ekonomi sosial budaya; dan hak komunitas kolektif. Ketiga generasi HAM tersebut dipayungi oleh dua konvensi internasional (baca: 'perangkat lunak') yang hampir semua negara-negara di dunia telah meratifikasi, yaitu: International Covenant on Civil and Political Rights (ICCPR) dan International Covenant on Economic, Social, and Cultural

10 Pasal 1 ayat (2) The Charter of the United Nations.

11 Pasal 1 ayat (3) The Charter of the United Nations.

12 Pasal 1 The Universal Declaration of Human Rights.

13 Oji Umozurike, "Human Rights and Development", The United Nations Educational, Scientific, and Cultural Organization (UNESCO), 1998, hlm. 536. 
Rights (ICESCR). Terlepas dari perbedaan fokus dan kajian, kedua konvensi HAM tersebut harus dilihat sebagai satu kesatuan yang seimbang, tidak kontradiktif satu sama lain dan saling tali-temali dalam prinsip kemanusiaan dan keberadaban bangsa. ${ }^{14}$

Generasi HAM ketiga yang dibahas dalam tulisan ini adalah hak komunitas kolektif yang salah satu aspek pentingnya adalah hak atas pembangunan inklusif, terutama untuk masyarakat termarginal, minoritas, dan adat. ${ }^{15}$ Hak ini bersifat nonindividualis, di mana kewajiban akan pemenuhannya tidak disandarkan pada bahu pemerintah semata, akan tetapi sebagai kewajiban semua komunitas bangsa. ${ }^{16}$ Dikarenakan begitu strategisnya cakupan dan dampak hak tersebut, maka diperlukan peran aktif pembuat kebijakan publik baik dalam level internasional maupun nasional.

\section{Hak Masyarakat Adat dalam Hukum Hak Asasi Manusia Internasional}

Publik internasional pernah terbelah pendapat tentang apa dan bagaimana kebijakan publik yang terbaik untuk masyarakat adat. Pendapat-pendapat tersebut dapat terbaca dalam dinamika di International Labor Organization (ILO). Konvensi ILO yang pertama, ILO Nomor 107 mendefinisikan masyarakat adat lewat perspektif patronasi; di mana masyarakat adat dibayangkan pada posisi pinggiran, sedangkan negara dan masyarakat non-adat/mayoritas berada di titik pusat. Perspektif ini berdasar pada tesis sentralisme hukum dan integrasi, di mana masyarakat adat harus melebur bersama masyarakat mayoritas guna menjemput zaman. Tesis ini kerap disebut sebagai strategi melting pot. ${ }^{17}$

Namun demikian, perspektif tersebut cepat tergantikan dengan perspektif yang lebih inklusif lewat Konvensi ILO Nomor 169 Tahun 1989 tentang Indigenious and Tribal Peoples (Konvensi ILO Nomor 169). Perspektif yang dipakai adalah salad bowl di mana tidak boleh ada daya upaya dari pemerintah untuk melakukan peleburan etnisitas secara sistematis dan terencana. Masyarakat adat diakui dan dihormati keberagaman dan keunikan budaya dan sistem sosialnya. ${ }^{18}$ Namun sayangnya, negara-negara Asia Tenggara dan pemerintah Indonesia sampai saat ini belum meratifikasi konvensi ini. Selain itu PBB pada tahun 2007 silam juga sudah mengeluarkan United Nations Declaration on the Rights of Indigenous Peoples

14 Ibid.

15 Heidemarie Wieczorek-Zeul, "Human Rights and Development", Environmental Policy and Law, Volume 38, Issue 5, 2008, hlm. 249.

16 Ibid.

17 Pasal 1 ayat (3), Pasal 2 ayat (1) dan (2) International Labor Organization Convention concerning the Protection and Integration of Indigenous and other Tribal and Semi-Tribal Populations in Independent Contries, 1957 (ILO Convention No. 107).

18 Pasal 1 (a) dan (b) International Labor Organization Convention concerning Indigenous and Tribal Peoples in Independent Countries, 1989 (ILO Convention No. 169). 
(UNDRIP) atau Deklarasi Hak Masyarakat Adat. ${ }^{19}$ Namun sama halnya dengan Konvensi ILO Nomor 169, UNDRIP dianggap semata sebagai deklarasi moral yang tidak mengikat secara hukum.

Terlepas dari banyaknya celah hukum di atas, Komisi HAM PBB atau UN Human Rights Committee (HRC), sebagai badan penafsir konvensi-konvensi HAM internasional, berpendapat bahwa masyarakat adat tetap dapat mengadvokasi hakhak mereka, dan pemerintah juga tetap harus menghormati hak-hak mereka lewat klausula minoritas yang terpatri dalam ICCPR, ICESC, dan dalam International Convention for the Elimination of All Forms of Racial Discrimination (ICERD). ${ }^{20}$ Setidaknya ada 4 (empat) isu krusial masyarakat adat yang memiliki pijakan normatif-doktrinal dari hukum HAM Internasional, yaitu hak atas kepemilikan kolektif, hak untuk berpartisipasi, hak mengelola SDA dan hak atas pembangunan.

\section{Hak atas Kepemilikan Kolektif}

Pengabaian pemerintah terhadap kepemilikan kolektif masyarakat adat dapat dianggap melanggar Pasal 27 dari ICCPR yang menyatakan bahwa pemerintah tidak boleh abai terhadap hak minoritas untuk dapat mengartikulasikan kebudayaannya. ICCPR menyatakan sebagai berikut:

"In those States in which ethnic, religious or linguistic minorities exist, persons belonging to such minorities shall not be denied the right, in community with the other members of their group, to enjoy their own culture, to profess and practice their own religion, or to use their own language." 21

Dalam konteks ini HRC menafsirkan 'kepemilikan kolektif' sebagai bagian integral dari kebudayaan masyarakat adat. ${ }^{22}$ Selain itu ICERD juga menyatakan "masyarakat adat memiliki hak yang sama dengan masyarakat non-adat." Oleh karena itu, Pasal 5 (d) (v) ICERD tentang larangan melakukan diskriminasi terhadap 'hak memiliki kepemilikan' juga berlalu untuk masyarakat adat. Rekomendasi ICERD menyatakan:

"Recognize and protect the right of indigenous peoples to own, develop, control and use their communal lands, territories and resources and, where they have been deprived of their lands and traditionally owned or otherwise inhabited or used without their free

\footnotetext{
19 United Nations Declaration on the Rights of Indigenous Peoples, GA Res 61/295, UN GAOR, $61^{\text {st }}$ sess, $107^{\text {th }}$ plen mtg. Supp No. 49, UN Document A/RES/61/295 (13 September 2007).

20 Lovelace v Canada, HRC, Communication No 24/1997, UN Document CCPR/C/13/D/24/1997 (30 Juli 1981), Hopu v France, HRC, Communication No 549/1993, UN Document CCPR/C/60/D/549/1993/Rev.1 (29 Juli 1997).

21 Pasal 27 International Covenant on Civil and Political Rights (ICCPR).

22 Human Rights Council, "CCPR General Comment 23: The Rights of Minorities” (8 April 1994).
} 
and informed consent, to take steps to return those lands and territories." 23

Selain itu, pasca dideklarasikannya UNDRIP, pranata hukum internasional banyak berubah; dari state-centered menuju community-centered. Perubahan paradigma dalam dilihat dari berubahnya rumusan United Nations Educational, Scientific, and Cultural Organization (UNESCO) Convention concerning the Protection of the World Cultural and Natural Heritage, di mana dinyatakan: "the State' duty to identify, protect, conserve and present indigenous tangible heritage found on their territory" ${ }^{24}$ (bahwa setiap negara memiliki kewajiban untuk mengidentifikasi, menjaga, dan menghormati warisan kebudayaan materiil yang ditemukan/dipraktikkan dalam wilayah mereka). Kepemilikan kolektif-komunal masyarakat adat dianggap memenuhi kualifikasi sebagai warisan kebudayaan materiil tersebut.

\section{Hak untuk Berpartisipasi}

Selain pengakuan terhadap 'pemilikan kolektif' yang termasuk dalam ekspresi kebudayaan masyarakat adat, hukum HAM internasional juga memberi hak kepada masyarakat adat untuk berpartisipasi aktif dalam proses pengambilan kebijakan pembangunan yang berdampak langsung maupun tidak langsung terhadap mereka. Hak partisipatif tersebut sejatinya telah dilekatkan kepada masyarakat adat lewat Pasal 32 UNDRIP sebagai hak spesifik masyarakat adat: "Right to give or withhold their free, prior and informed consent to actions that affects their lands, territories and natural resources." ${ }^{25}$ Konvensi ILO Nomor 169 menambahkan: “...through appropriate procedures and in particular through their representative" 26 "...to decide upon their own priorities for development, which includes development affecting theirlands". ${ }^{27}$

Prosedur-prosedur yang menjamin hak partisipatif tersebut dinamakan FPIC (Free, Prior and Informed Consent). FPIC sendiri terdiri dari 4 (empat) unsur inheren: Free (bebas), di mana dalam proses komunikasi awal dan negosiasi tidak ada unsur paksaan, manipulasi, intimidasi dan intervensi dari pihak manapun kepada masyarakat adat; Prior (sebelum), di mana diartikan pihak-pihak yang berkepentingan dengan SDA masyarakat adat harus terlebih dahulu memiliki kesepakatan sebelum proyek pembangunan dilaksanakan; Informed (diinformasikan), diartikan masyarakat adat berhak mendapatkan sebanyak mungkin

23 International Convention on the Elimination of All Forms of Racial Discrimination, "General Recommendation XXIII: Indigenous Peoples", 18 Agustus 1997.

24 Pasal 4 UNESCO Convention concerning the Protection of the World Cultural and Natural Heritage.

25 Pasal 32 United Nations Declaration on the Rights of Indigenous Peoples, GA Res 61/295, UN GAOR,61 ${ }^{\text {st }}$ sess, $107^{\text {th }}$ plen mtg. Supp No 49, UN Document A/RES/61/295 (13 September 2007).

26 Pasal 6(1) (a) ILO Convention No. 107.

27 Pasal 7 (1) ILO Convention No. 107. 
informasi terkait proyek pembangunan; dan terakhir, Consent (kesepakatan), diartikan sebagai kesepakatan dengan masyarakat adat yang menjadi 'kunci' bagi terselenggaranya proyek pembangunan; tidak ada proyek pembangunan, tanpa adanya kesepakatan. ${ }^{28}$ Memperkuat argumen di atas, HRC secara tegas menyatakan pentingnya partisipasi efektif (FPIC) dari masyarakat adat minoritas untuk terlibat dalam proses pengambilan kebijakan pembangunan. ${ }^{29}$

Selain itu, ICERD juga menekankan bahwa alpanya pemerintah akan hak partisipasi masyarakat adat merupakan wujud pelanggaran terhadap Pasal 5 (c) ICERD: "Political rights, in particular the right to participate ... as well as in the conduct of public affairs at any level. ${ }^{30 "}$ (Memiliki hak politik, khususnya hak berpartisipasi ... juga dalam hal yang melibatkan hubungan publik di semua level). Masyarakat adat memiliki kesamaan hak untuk berpartisipasi dalam proses pengambilan kebijakan dan pembangunan. Hak masyarakat adat untuk mengontrol pembangunan (to control) ditafsirkan mencakupi proses-proses negosiasi dan konsultasi dengan pihak-pihak yang berkepentingan dalam proyek pembangunan.

\section{Hak Mengelola Sumber Daya Alam}

Isu krusial lain yang dibahas oleh hukum HAM internasional adalah tentang hak masyarakat adat untuk mengelola SDA yang berada dalam penguasaan komunalnya. Dalam penafsiran umum, Pasal 47 ICCPR memberi pengaturan bahwa: "... peoples have right to enjoy and utilize fully and freely their natural wealth and resources". ${ }^{31}$ Karena strategisnya isu pengelolaan SDA, Pasal 47 ICCPR masih sering diperdebatkan dalam forum internasional, yakni apakah kata 'peoples' merujuk pada masyarakat adat atau tidak. Beberapa negara berkilah bahwa rumusan pasal bersifat umum, tidak spesifik mengatur tentang masyarakat adat.

Namun HRC menafsirkan kata 'peoples' mencakup juga masyarakat adat. Lewat periodic review di beberapa negara, HRC menemukan banyak proyek-proyek pembangunan yang menafikan hak-hak masyarakat adat, di mana lingkungan dan pranata hidup masyarakat adat terganggu oleh proyek-proyek 'pembangunan' yang ekspansif dan diskriminatif. Praktik tersebut sejatinya melanggar Pasal 27 ICCPR ${ }^{32}$ Selain itu HRC juga menyatakan bahwa hukum HAM internasional merupakan struktur yang sistematis dan holistik, bukan sistem yang tunggal dan berdiri sendiri. Oleh karena itu, isu masyarakat adat terutama terkait hak pengelolaan atas SDA harus juga dipahami dalam kerangka normatif-makro yaitu hak menentukan nasib sendiri dalam Pasal 1 ICCPR dan ICESCR. ${ }^{33}$

28 Oxfam Australia, Citizens Guide to Free, Prior, Informed and Consent, Baguio City, 11 April 2011, hlm. 3.

29 Human Rights Council, "General Comment 23: The Right of Minorities", Loc.cit.

30 Pasal 5 International Convention on the Elimination of All Forms of Racial Discrimination (ICERD).

31 Pasal 47 ICCPR.

32 Pasal 27ICCPR.

33 Human Rights Committee, Lubicon Lake Band v Canada, Communication No 167/1984, UN Document 


\section{Hak atas Pembangunan}

Hak pamungkas yang melingkupi semua isu-isu krusial tentang hak masyarakat adat adalah hak atas pembangunan (right to development) yang merupakan simbol perlawanan HAM terhadap aliran developmentalisme. Tonggak sejarah perjuangan dimulai pada tahun 1986 dengan diselenggarakannya The Declaration on The Right to Development (DRD). DRD menyatakan bahwa hak atas pembangunan memiliki substansi yang inklusif dengan menggabungkan dan tidak membeda-bedakan antara Hak Sipil dan Politik (Pasal 1-21), dan Hak Ekonomi, Sosial, dan Budaya (Pasal 22-28) yang terpatri dalam rumusan UDHR. ${ }^{34}$ DRD kemudian lebih diperkuat dengan dimasukkan substansinya ke dalam the Second UN World Conference on Human Rights pada tahun 1993. Konferensi ini kerap disebut sebagai Declaration on the Right to Development yang kedua (DRD II). Deklarasi ini memuat banyak materi normatif tentang relasi antara manusia/masyarakat (tidak hanya warga negara) dan pemerintah. Masyarakat berhak untuk berpartisipasi aktif (central subject to development), untuk berkontribusi proaktif (to actively contribute), dan menikmati (to enjoy) baik Hak Sipil dan Politik dan juga Ekonomi, Sosial dan Budaya, lewat pembagian keuntungan yang seadil-adilnya. ${ }^{35}$

Arjun Sengupta memberi komentar tentang perbedaan mencolok antara hak atas pembangunan dengan doktrin pembangunan developmentalisme; hak atas pembangunan berorientasi pada kualitas dari masyarakat, sedangkan doktrin pembangunan developmentalisme hanya semata berkutat pada aspek kuantitas dari nilai-nilai kuantitatif pertumbuhan perekonomian suatu negara. ${ }^{36}$

Secara garis besar, hak atas pembangunan dalam DRD II memiliki esensi argumen sebagai berikut: (1) Deklarasi menyatakan bahwa hak atas pembangunan adalah HAM; dengan kata lain HAM harus menjadi prasyarat dari kebijakan dan pelaksanaan pembangunan; (2) hak atas pembangunan berkarakter inklusif, dimana kedua hak yang diatur dalam konvensi ICCPR dan ICESR adalah bagian tidak terpisahkan dan tali-temali satu sama lain, ini berkesesuaian dengan karakter HAM yang indivisible and interdependent; (3) pelaksanaan hak atas pembangunan harus dibarengi dengan prinsip kebebasan, yang berarti proses pembangunan harus dilakukan secara transparan, terbuka, akuntable, memberi distribusi keuantungan yang adil kepada masyarakat sekitar; (4) kewajiban untuk menjaga pemenuhan terhadap hak atas pembangunan ini, diberikan kepada manusia/warga negara/masyarakat dan juga terhadap pemerintah.

\section{CCPR/C/38/D/167/1984 (1990).}

34 The Declaration on the Right to Development (DRD), 1986.

35 Pasal 10 dan 11 The Second UN World Conference on Human Rights 1993.

36 Arjun Sengupta, "Right to Development as a Human Right", Economic and Political Weekly, Juli 7, 2001, hlm. 2528. 
Melalui deskripsi teoritik-normatif di atas, dapat tergambar bahwa pranata hukum internasional telah memberi rambu-rambu normatif yang kuat terhadap perlindungan masyarakat adat vis-à-vis program 'pembangunan' ekstraktif. Namun sebagai wujud supremasi hukum negara, norma-norma tersebut perlu diinternalisasi baik lewat ratifikasi maupun adopsi ke dalam sistem hukum negara Indonesia. Sejauh mana Indonesia telah melakukan reformasi di bidang HAM pada umumnya dan perlindungan masyarakat adat pada khususnya, akan dielaborasi dalam pembahasan berikut.

\section{Telaah Hukum Sumber Daya Alam dan Hak Asasi Manusia Nasional}

Indonesia pasca otoritarianisme berbenah dalam segala hal, terutama dalam ikhtiar memperbaiki pranata hukum, demokrasi, dan keadilan sosial. Zaman pasca otoritarianisme dianggap sebagai 'tapal batas' antara; zaman dulu Orde Baru yang otoritarian dengan zaman reformasi yang progresif, bersih dan bervisi negara hukum. Amandemen konstitusi menjadi suatu keniscayaan dalam merubah paradigma kenegaraan menjadi negara hukum substantif, bukan semata prosedural. $^{37}$

Aspirasi terhadap jaminan akan pemenuhan HAM baru diakomodir dalam Perubahan Kedua, di mana Pasal 28 tentang HAM dirombak dan bertambah dari hanya satu pasal (Pasal 28) menjadi Pasal 28A hingga 28J. Perubahan tersebut menandakan pemerintah Indonesia sudah berkomitmen untuk memperbaiki relasi negara dengan warga negara lewat bingkai HAM yang humanis dan berkeadilan.

Dalam konteks perlindungan masyarakat adat, jaminan akan perlindungan hak masyarakat adat terpatri dalam 3 (tiga) pasal konstitusi, yaitu: Pasal 18B Ayat (2); Pasal 281 Ayat (3); dan Pasal 32 Undang-Undang Dasar 1945 (UUD 1945). Namun rumusan pasal-pasal yang dirasa paling krusial adalah Pasal 18B Ayat (2) yang berdimensi pemerintah daerah (walaupun menyebut juga tentang hak asal usul) dan Pasal 28I Ayat (3) yang berdimensi HAM. Walau sudah diatur dalam norma konstitusi, Dewan Perwakilan Rakyat (DPR) cenderung enggan mengelaborasi baik Pasal 18B ayat (2) dan Pasal 281 ayat (3) dalam bentuk produk undang-undang organik. Putusan MK 35 sebagai 'kotak pandora' hak masyarakat adat merupakan produk badan yudikatif (dalam hal ini Mahkamah Konstitusi), dan gugatan bukan atas inisiasi DPR, melainkan hasil perjuangan pergerakan civil society, terutama oleh Aliansi Masyarakat Adat Nusantara (AMAN) lewat judicial review UU Kehutanan 1999. Baru setelah momentum Putusan MK 35 kemudian DPR mengadopsi nilainilai Putusan MK 35 dalam UU Desa yang juga mengatur tentang Desa Adat.

Dalam bagian ini, beberapa peraturan perundang-undangan sektoral yang relevan terhadap topik SDA, pembangunan, dan hak masyarakat adat akan dianalisa

37 Suparman Marzuki, Tragedi Politik Hukum HAM, Yogyakarta: Pusham UII, 2011, hlm. 124. 
dengan menggunakan teori hak atas pembangunan (right to development) yang merupakan perlawanan terhadap paradigma developmentalisme.

\section{Peraturan tentang Desa}

UU Desa memakai dua konsep pendekatan, yaitu local self-community yang dijalankan oleh desa-desa konvensional (non-adat) sebagai manifestasi dari kebijakan publik, dan self-governing community lewat desa-desa adat yang merupakan manifestasi dari semangat demokrasi lokal. Lewat demokrasi lokal yang kontekstual inilah desa adat diharapkan dapat menjadi wadah persemaian tradisi masyarakat adat di Indonesia. Secara umum, UU Desa mengatur tentang pengaturan dan pengurusan ulayat atau wilayah adat. ${ }^{38}$ Dapat ditafsirkan bahwa UU Desa mengayomi konsep kepemilikan kolektif oleh masyarakat adat. Selain itu, penyebutan kata 'desa' juga dianggap sebagai sebuah pilihan (optional), karena 'desa' dianggap sebagai entitas budaya yang cair dan kontekstual di mana keberagaman antar desa-desa adat adalah suatu keniscayaan. Namun terkait hak atas pengelolaan SDA, Pasal 103 UU Desa tidak mencantumkannya dalam bagian kewenangan Desa Adat berdasarkan hak asal usul.

Dalam konteks hak partisipasi, UU Desa memberi ruang yang luas dengan mendorong partisipasi publik di desa dalam menentukan status desa mereka; apakah ingin menjadi desa adat, atau menjadi desa non-adat. ${ }^{39}$ Selain itu, kriteria masyarakat adat juga lebih fleksibel jika dibandingkan dengan UU Kehutanan 1999. Untuk dapat diakui sebagai entitas hukum, masyarakat adat harus dapat membuktikan bahwa mereka memiliki wilayah (tanah) adat dan memiliki setidaknya satu dari beberapa kriteria fakultatif lain. ${ }^{40}$ Prosedur pengakuan masyarakat adat juga lebih partisipatif dengan bersifat bottom-up, dengan lebih menghargai partisipasi dan kontribusi publik, walaupun peran strategis kepala daerah sebagai pemberi hak pengakuan masih sangat kuat. ${ }^{41}$

Namun progresifnya peran partisipatif masyarakat adat dalam prosedur pengakuan di atas terhambat oleh terbaginya jalur proses pengakuan masyarakat adat dengan pemberian hak atas tanah/hutan adat mereka, sehingga terkesan

38 Pasal 103 huruf (b) Undang-Undang Nomor 6 Tahun 2014 tentang Desa (UU Desa).

39 Pasal 100 ayat (1) UU Desa: "Status Desa dapat diubah menjadi Desa Adat, kelurahan dapat diubah menjadi Desa Adat, Desa Adat dapat diubah menjadi Desa, dan Desa Adat dapat diubah menjadi kelurahan berdasarkan prakarsa masyarakat yang bersangkutan melalui Musyawarah Desa dan disetujui oleh Pemerintah Daerah Kabupaten/Kota."

40 Pasal 97 ayat (2) UU Desa:

“... harus memiliki wilayah dan paling kurang memenuhi salah satu atau gabungan unsur adanya:

a. masyarakat yang warganya memiliki perasaan bersama dalam kelompok;

b. pranata pemerintahan adat;

c. harta kekayaan dan/atau benda adat; dan/atau

d. perangkat norma hukum adat."

41 Yando Zakaria, "Menimbang-nimbang Kemaslahatan Undang-Undang Desa", https://independent.academia.edu/YandoZakaria, diunduh 2 Februari 2017. 
sangat birokratis dan tidak efektif. Pengakuan masyarakat adat sebagai legal entity melalui Peraturan Daerah (Perda) yang dikeluarkan oleh kepala daerah lewat proses politik yang panjang dengan Dewan Perwakilan Rakyat Daerah (DPRD), sebagaimana diatur dalam UU Kehutanan 1999,42 atau lewat SK bupati/walikota berdasarkan Peraturan Menteri Dalam Negeri. ${ }^{43}$ Sedangkan sertifikat tanah komunal atau hutan adat didaftarkan lewat Badan Pertanahan Nasional (BPN) sebagaimana diatur dalam Peraturan Menteri Agraria dan Tata Ruang. ${ }^{44}$ Dalam jalur desentralisasi, UU Desa mengatur tentang proses penetapan desa adat, yang harus didahului oleh Perda setempat. ${ }^{45}$ Pecahnya proses pengakuan masyarakat adat menjadi beberapa jalur birokratis di atas menandakan belum padunya pemahaman dan konsolidasi tentang hak-hak masyarakat dalam level pengambilan kebijakan.

Proses pengakuan seharusnya bisa lebih disederhanakan dan diatur secara holistik dan tidak terlalu birokratis; apabila masyarakat adat yang bermukim di wilayah komunal-adatnya sudah diakui sebagai legal entity, maka seharusnya tanah/hutan adat yang mereka huni juga diakui keabsahannya sebagai kepemilikan adat, dan masyarakat adat segera dapat mengajukan permohonan penetapan desa adat atau hutan adat kepada kementerian terkait. ${ }^{46}$ Jalur yang lebih efektif dan efisien adalah lewat proses penetapan desa adat, sebagaimana sudah diamanahkan oleh UU Desa. Namun demikian, apabila pemerintah daerah terkait terkesan 'malas' melakukan identifikasi dan mengakui eksistensi masyarakat adat secara legal, maka adalah suatu keniscayaan bagi struktur pemerintah pusat (Kementerian KLH dan Komnas HAM) untuk 'turun gunung' membantu melakukan proses-proses pengakuan.

Terlepas dari pengaturan perihal prosedur pengakuan dan penetapan desa adat di atas, UU Desa masih lemah dalam pengaturan untuk membentengi masyarakat adat dari proyek 'pembangunan'. Walau dalam Pasal 108 UU Desa dijelaskan juga tentang peran musyawarah dalam Desa Adat, ${ }^{47}$ namun tidak diperinci bagaimana musyawarah desa dapat membantu proses negosisasi dan konsultasi dalam proses pembangunan. UU Desa tidak memberi deskripsi norma yang mencukupi untuk melakukan prosedur FPIC dalam proyek 'pembangunan' di wilayah masyarakat adat. Cacat hukum ini agak mengkhawatirkan karena UU Desa membuka kesempatan untuk penghapusan suatu desa untuk 'kepentingan program nasional yang strategis'. ${ }^{48}$

42 Pasal 67 ayat (2) Undang-Undang Nomor 41 Tahun 1999 tentang Kehutanan.

43 Peraturan Menteri Dalam Negeri Nomor 52 Tahun 2014 tentang Pedoman Pengakuan dan Perlindungan Masyarakat Hukum Adat.

44 Peraturan Menteri Agraria dan Tata Ruang Nomor 10 Tahun 2016 tentang Tata Cata Penetapan Hak Komunal atas Tanah Masyarakat Hukum Adat dan Masyarakat yang Berada dalam Kawasan Tertentu.

45 Pasal 98 UU Desa.

46 Kompas, "Pengakuan Hak: Masyarakat Adat Menanti, Persingkatan Birokrasi”, Kompas, 14 Januari 2017, hlm. 5.

47 Pasal 108 UU Desa.

48 Pasal 9 UU Desa. Dalam Penjelasan disebutkan tentang definisi kepentingan program nasional yang strategis 


\section{Peraturan tentang 'Kepentingan Umum/Nasional'}

Definisi 'kepentingan umum' atau 'kepentingan program nasional yang strategis' sudah diberikan oleh beberapa produk legislasi, misalnya pada Keputusan Presiden Nomor 55 Tahun 1993 tentang Pengadaan Tanah bagi Pelaksanaan Pembangunan untuk Kepentingan Umum (Keppres 55/1993) dan juga Undang-Undang Nomor 2 Tahun 2012 tentang Pengadaan Tanah bagi Pembangunan untuk Kepentingan Umum (UU Pengadaan Tanah bagi Pembangunan). Keppres 55/1993 lahir di zaman Orde Baru namun secara normatif produk hukum eksekutif ini cukup responsif dengan memberi ruang musyawarah dan ganti kerugian dalam proses pengadaan tanah untuk pembangunan. ${ }^{49}$ Namun terhadap penggantian tanah yang dikuasai oleh hak ulayat, dinyatakan: "...diberikan dalam bentuk pembangunan fasilitas umum .... ${ }^{50}$ Praktik ini dapat dipahami sebagai asimilasi sosial budaya dan pembangunan yang dipaksakan.

UU Pengadaan Tanah bagi Pembangunan menekankan aspek 'keseimbangan antara kepentingan pembangunan dan masyarakat'. Selain itu, UU Pengadaan Tanah bagi Pembangunan ini menjelaskan tentang hak-hak pihak yang berhak untuk "a. mengetahui rencana penyelenggaraan Pengadaan Tanah; dan b. memperoleh informasi mengenai Pengadaan Tanah". ${ }^{51}$ Dalam penyelenggaraan Pengadaan Tanah untuk Kepentingan Umum, masyarakat dapat berperan serta, antara lain: "a. memberikan masukan secara lisan atau tertulis mengenai Pengadaan Tanah; dan b. memberikan dukungan dalam penyelenggaraan Pengadaan Tanah". ${ }^{52}$

Namun demikian, definisi dan paramenter dari 'kepentingan nasional' dan 'keseimbangan' tidak dielaborasi dengan tuntas, demikian juga dengan bagaimana proses partisipasi dijalankan, proporsi warga yang dilibatkan dan peran aktif perempuan, remaja, dan juga masyarakat adat tidaklah diatur secara mendetail dalam UU ini. Alpanya definisi 'kepentingan nasional/umum' ini berpotensi menjadi 'pasal karet' yang dapat digunakan untuk semata mengayomi kepentingan elit pemerintah dan kuasa investor ekonomi ekstraktif. UU ini telah di-judicial review, namun gugatan ditolak sepenuhnya oleh Mahkamah Konstitusi (MK). ${ }^{53}$

\footnotetext{
sebagai: "...program pembuatan waduk atau bendungan yang meliputi seluruh wilayah Desa."

49 Pasal 9, 10, 11, dan 12 Keputusan Presiden Nomor 55 Tahun 1993 tentang Pengadaan Tanah bagi Pelaksanaan Pembangunan untuk Kepentingan Umum (Keppres 55/1993).

50 Pasal 14 Keppres 55/1993.

51 Pasal 55 Undang-Undang Nomor 2 Tahun 2012 tentang Pengadaan Tanah bagi Pembangunan untuk Kepentingan Umum (UU Pengadaan Tanah bagi Pembangunan)

52 Pasal 56 UU Pengadaan Tanah bagi Pembangunan.

53 Putusan Mahkamah Konstitusi Nomor 50/PUU-X/2012 tentang Permohonan Pengujian Undang-Undang Nomor 2 Tahun 2012 tentang Pengadaan Tanah Bagi Pembangunan untuk Kepentingan Umum terhadap Undang-Undang Dasar 1945, putusan diucapkan dalam sidang Pleno Mahkamah Konstitusi yang terbuka untuk umum pada hari Rabu, 13 Februari 2013.
} 


\section{Peraturan tentang Pertambangan}

Dalam konteks SDA dan masyarakat adat, UU yang paling tidak responsif terhadap hak-hak masyarakat adat adalah Undang-Undang Nomor 4 Tahun 2009 tentang Pertambangan Mineral dan Batubara (UU Minerba). UU ini bahkan di bagian Ketentuan Umum tidak sedikitpun menyinggung tentang masyarakat adat dan hakhak komunal mereka atas tanah/hutan. Padahal dalam praktiknya banyak sekali tanah/hutan adat yang tumbang tindih dengan Wilayah Pertambangan (WP). ${ }^{54}$

UU Minerba terang benderang lebih memihak pada kebijakan pengutamaan ekstraksi mineral dan/atau batubara guna menunjang 'pembangunan'. Pasal 5 menyebutkan bahwa "Untuk kepentingan nasional, Pemerintah setelah berkonsultasi dengan DPR RI dapat menetapkan kebijakan pengutamaan mineral dan/atau batubara untuk kepentingan dalam negeri". ${ }^{55}$ Diksi 'kepentingan nasional' kembali menjadi mantra sakti pemerintah untuk melakukan proyek-proyek pembangunan ekstraktif. UU Minerba juga tidak memberi penjelasan terhadap diksi 'kepentingan nasional' tersebut.

Terkait proses penetapan WP, UU Minerba dalam Pasal 10 terkesan responsif dengan menyatakan bahwa proses penetapan dilakukan: "a. secara transparan, partisipatif, dan bertanggung jawab; b. secara terpadu dengan memperhatikan pendapat dari instansi pemerintah terkait, masyarakat, dan dengan mempertimbangkan aspek ekologi, ekonomi, dan sosial budaya, serta berwawasan lingkungan; dan c. dengan memperhatikan aspirasi daerah". ${ }^{56}$ Namun bagaimana teknis penyerapan aspirasi daerah dan partisipasi masyarakat itu tidak dijelaskan secara terperinci dan konkret, dan hal-hal terkait hak masyarakat atas partisipasi tersebut tidak diatur dalam peraturan teknis/turunan dari UU ini. ${ }^{57}$ Sehingga rumusan norma-norma di atas ini terkesan hanya sebagai 'pemanis' saja.

Dalam Pasal 67 ayat (1) UU Minerba memang membuka peluang untuk perizinan pertambangan rakyat (IPR). ${ }^{58}$ Namun norma tersebut tidak relevan bagi masyarakat adat, karena secara sosiologis-kultural masyarakat adat bukanlah penambang. Norma ini malah dapat digunakan oleh kalangan-kalangan pengusaha lokal di daerah untuk menambang (baca: mempercepat penghancuran lingkungan) di daerah-daerah adat. Dapat disimpulkan bahwa UU Minerba sangat terpengaruh dengan paradigma developmentalisme dan abai terhadap hak-hak pembangunan masyarakat adat.

54 Mongabay, "Masyarakat Adat Matteko Berjuang Mengembalikan Hutan yang Terampas", http://www.mongabay.co.id/2013/07/30/masyarakat-adat-matteko-berjuang-mengembalikan-hutan-yangterampas/, diakses 3 Februari 2017.

55 Pasal 5 Undang-Undang Nomor 4 Tahun 2009 tentang Pertambangan Mineral dan Batubara (UU Minerba).

56 Pasal 10 (a), (b) dan (c) UU Minerba.

57 Peraturan Pemerintah Nomor 23 Tahun 2010 tentang Pelaksanaan Kegiatan Pertambangan Mineral dan Batubara.

58 Pasal 67 ayat (1) UU Minerba. 


\section{Peraturan tentang Perkebunan}

Tidak semua produk legislasi dalam bidang SDA menafikan kedudukan masyarakat adat, pasca judicial review di MK pada medio 2010 silam, Undang-Undang Nomor 39 Tahun 2014 tentang Perkebunan (UU Perkebunan) sekarang memberi ramburambu norma hukum yang kuat bagi masyarakat adat. Paradigma pluralisme hukum terlihat di bagian Ketentuan Umum, di mana UU Perkebunan menjelaskan secara jelas tentang definisi masyarakat adat dan hak-hak ulayat mereka. ${ }^{59}$ Lebih lanjut, diberikan "larangan bagi pejabat yang berwenang untuk menerbitkan Usaha Perkebunan (UP) di atas tanah ulayat masyarakat adat". ${ }^{\circ}$ Dan juga diberikan larangan bagi setiap orang secara tidak sah "untuk mengerjakan, menggunakan, menduduki dan/atau menguasai tanah masyarakat atau tanah hak ulayat masyarakat adat untuk UP". ${ }^{61}$ Dari rumusan pasal-pasal yang sangat tegas dan eksplisit tersebut dapat disimpulkan bahwa UU Perkebunan mengakui adanya kepemilikan kolektif masyarakat adat terhadap tanah/hutan adat mereka.

Selain itu, dalam konteks hak partisipasi masyarakat adat, UU Perkebunan juga menekankan pentingnya mekanisme musyawarah dengan masyarakat adat pemegang hak ulayat dalam proses persetujuan penyerahan tanah dan imbalannya. ${ }^{62}$ Lebih detail, UU Perkebunan juga menyatakan bahwa:

"penyelenggaraan perkebunan harus melibatkan peran masyarakat dalam hal: (a) penyusunan perencanaan; (b) pengembangan kawasan;

(c) penelitian dan pengembangan; (d) pembiayaan; (e) pemberdayaan;

(f) pengawasan; (g) pengembangan sistem data dan informasi; (h)

pengembangan kelembagaan, dan/atau (i) perumusan pedoman perkebunan."63

Namun, bukan berarti UU ini tidak memiliki cacat normatif, walau UU mengharuskan: “...pelaku usaha (perusahaan) untuk melakukan musyawarah dengan masyarakat adat". ${ }^{64}$ Musyawarah dalam hal penyerahan lahan kepada perusahaan dilaksanakan sesuai dengan ketentuan pemerintah. Hal ini menunjukkan bahwa pemerintah masih enggan memberikan hak partisipasi (FPIC) secara penuh kepada masyarakat adat.

\footnotetext{
59 Pasal 1 ayat (5) dan (6) Undang-Undang Nomor 39 Tahun 2014 tentang Perkebunan (UU Perkebunan).

60 Pasal 17 ayat (1) UU Perkebunan.

61 Pasal 55 ayat (b) UU Perkebunan.

62 Pasal 12 ayat (1) UU Perkebunan.

63 Pasal 100 ayat (1) dan (2) UU Perkebunan.

64 Pasal 12 ayat (1) UU Perkebunan.
} 


\section{Peraturan tentang Kehutanan}

Apabila dalam sektor perkebunan, hak masyarakat adat 'cukup' aman dengan rambu-rambu normatif di atas, lain halnya dalam sektor kehutanan. Walaupun UU Kehutanan 1999 sudah beberapa kali diuji norma hukumnya oleh MK, Pemerintah dan DPR terkesan acuh untuk melakukan revisi terhadap UU Kehutanan 1999. Alihalih, Pemerintah dan DPR mengeluarkan Undang-Undang Nomor 18 Tahun 2013 tentang Pencegahan dan Pemberantasan Perusakan Hutan (UU P2H). Apabila dibaca dalam secara doktrinal, UU P2H terkesan responsif dengan menyatakan "pencegahan dan pemberantasan kerusakan hutan berasaskan: partisipasi masyarakat, ${ }^{65}$ dan melingkupi peran serta masyarakat". ${ }^{66} \mathrm{UU}$ P2H juga menjelaskan bahwa 'masyarakat' dalam UU ini mencakup juga 'masyarakat adat'. Peran serta masyarakat diatur secara rinci dalam UU ini. ${ }^{67}$ Walau tidak serinci FPIC, UU ini mencukupi untuk menyerap partisipasi masyarakat.

Kontradiksi terlihat pada rumusan pasal yang mengecualikan masyarakat adat dari definisi 'kelompok yang terorganisir (merusak hutan)', yang menyatakan: “...tidak termasuk kelompok masyarakat yang bertempat tinggal di dalam dan/atau di sekitar kawasan hutan yang melakukan perladangan tradisional...untuk keperluan sendiri dan tidak untuk tujuan komersial". ${ }^{68}$ Rumusan pasal ini terkesan progresif karena mengecualikan masyarakat adat dari 'kelompok yang terorganisir' diatas.

Namun demikian, dalam rumusan ayat selanjutnya dinyatakan:

"masyarakat yang bertempat tinggal di dalam dan/atau di sekitar kawasan hutan yang melakukan penebangan kayu di luar kawasan hutan konservasi dan hutan lindung untuk keperluan sendiri dan tidak untuk tujuan komersial harus mendapatkan izin dari pejabat yang berwenang sesuai dengan ketentuan perundang-undangan." ${ }^{69}$

Rumusan pasal di atas dapat dipahami sebagai upaya pelestarian hutan yang represif lewat perizinan yang berlebihan; masyarakat adat harus memiliki izin dari pejabat yang berwenang sebelum menebang kayu untuk keperluan sendiri (tanpa motif ekonomi). Selain itu diksi 'kawasan hutan' juga problematik, karena sebenarnya diksi 'kawasan hutan' sudah dibatalkan oleh MK. ${ }^{70}$

65 Pasal 2 ayat (d) Undang-Undang Nomor 18 Tahun 2013 tentang Pencegahan dan Pemberantasan Kerusakan Hutan (UU Pencegahan dan Pemberantasan Kerusakan Hutan).

66 Pasal 4 huruf (d) dan Pasal 6 ayat (3) UU Pencegahan dan Pemberantasan Kerusakan Hutan.

67 Pasal 58-61 UU Pencegahan dan Pemberantasan Kerusakan Hutan

68 Pasal 11 ayat (3) UU Pencegahan dan Pemberantasan Kerusakan Hutan

69 Pasal 11 ayat (4) UU Pencegahan dan Pemberantasan Kerusakan Hutan

70 Lihat Putusan Mahkamah Konstitusi Nomor 45/PUU-IV/2011 tentang Pengujian Undang-Undang Nomor 41 Tahun 1999 tentang Kehutanan. Putusan diucapkan dalam sidang Pleno Mahkamah Konstitusi yang terbuka untuk umum pada hari Selasa, 21 Februari 2012. 
Selain lewat produk legislasi sektoral yang mengatur tentang SDA, hak-hak masyarakat adat juga disokong oleh instrumen norma-norma HAM Internasional yang sudah diratifikasi oleh pemerintah Indonesia, selain Undang-Undang Nomor 39 Tahun 1999 tentang Hak Asasi Manusia (UU HAM). ICCPR sudah diratifikasi lewat Undang-Undang Nomor 12 Tahun 2005, demikian juga halnya dengan ICESCR yang diratifikasi lewat Undang-Undang Nomor 11 Tahun 2005, dan ICERD yang diratifikasi lebih dulu lewat Undang-Undang Nomor 29 Tahun 1999.

Walaupun konvensi-konvensi tersebut tidak secara khusus mengatur tentang hak masyarakat adat, namun HRC sudah memberi penafsiran terhadap beberapa pasal-pasal terkait yang juga dapat diberlakukan untuk masyarakat adat. Dengan diratifikasinya instrumen HAM tersebut, Pemerintah Indonesia tidak hanya terikat secara hukum oleh pasal-pasal dalam Konvensi-Konvensi tersebut, akan tetapi juga terikat oleh tamsil HRC terhadap Konvensi-Konvensi tersebut. Hal ini berkesesuaian dengan norma hukum dalam Konvensi Wina 1969 tentang Hukum Perjanjian (Internasional) di mana disebutkan hukum nasional tidak boleh menjadi pembenar diingkarinya kewajiban internasional.

\section{E. Penutup}

Dalam tata kelola administrasi negara, pepatah Perancis menyatakan; gouverner c'est prevoir, memerintah adalah memprediksi. Hal inilah yang harus menjadi tugas utama dari pemerintah Indonesia kedepannya. Pasca penetapan desa-desa adat, pemerintah juga harus mencari cara yang terefektif untuk memberi pengakuan dan keadilan sosial bagi masyarakat adat. Penetapan desa adat lewat Kementerian LHK merupakan hal yang baik, namun sebaiknya pemerintah harus aktif dalam mengkonsolidasi dan memetakan daerah-daerah masyarakat adat di seluruh Indonesia, tanpa harus menunggu inisiatif pemerintah daerah. Memang kebijakan ini terkesan sentralistik dan mencederai asas desentralisasi, namun fakta di lapangan sulit menemukan pemerintah daerah yang secara tulus berikhtiar untuk mengakui masyarakat adat.

Dalam ranah perundang-undangan, pemerintah perlu segera fokus untuk melakukan revisi UU Kehutanan 1999 secara holistik, sebagai ikhtiar untuk mentransformasi nilai-nilai reformis dalam Putusan MK 35. Selain itu, UU Minerba juga perlu segera direvisi. Dalam ranah perlindungan HAM, diperlukan adanya Undang-Undang Perlindungan Hak-Hak Masyarakat Adat yang diposisikan sebagai tandem UU Desa dalam ranah desentralisasi, dan sebagai 'payung' UU HAM dan untuk melengkapi UU sektoral SDA. UU tersebut diharapkan dapat mengambil substansi Konvensi ILO Nomor 169 terutama dalam aspek-aspek penting yang sudah dielaborasi dalam pembahasan di atas. Tidak kalah krusial, pemerintah Indonesia seharusnya mengadopsi pasal-pasal substansitif tentang hak 
pembangunan dalam the Second UN World Conference on Human Rights pada tahun 1993 yang merupakan penyempurnaan dari The Declaration on the Right to Development.

Pada akhirnya, memang peraturan perundang-undangan memiliki kelemahan; sifat yang statis dan umum. Sehingga kadang dalam tataran konseptual bagus, namun dalam implementasi kerap ditafsirkan secara keliru oleh penegak hukum (polisi hutan, polisi, jaksa dan hakim). Hal tersebut menyebabkan proses pembangunan tidak hanya menjadi ranah eksklusif pemerintah dan pelaku usaha saja, akan tetapi harus menjadi ranah yang inkusif dan partisipatif bagi semua. Agar tercipta pembangunan yang tidak semata dipahami sebagai angka-angka kuantitatif-statistik semata, namun harus kaya akan perspektif HAM. Semoga.

\section{Daftar Pustaka}

\section{Buku}

Colfer dan Resosudarmo (eds), Which Way Forward? Forest, Peoples and Policies in Indonesia, Institute of Southeast Asian Studies, 2001.

Duncan, Christopher R. (ed), Civilizing the Margins: South-East Asia Government Policies for the Development of Minorities, Cornell University Press, 2004.

Oxfam Australia, Citizens Guide to Free, Prior, Informed and Consent, Baguio City, 11 April 2011.

Ribot, Waiting for Democracy: The Politics of Choice in Natural Resources Decentralization, World Resources Institute, 2004.

Suparman Marzuki, Tragedi Politik Hukum HAM, Pusham UII, Yogyakarta, 2011.

\section{Dokumen Lain}

Beckert, Barbara, Christoph Dittrich, dan Soeryo Adiwibowo, "Contested Land: An Analysis of Multi-Layered Conflicts in Jambi Province, Sumatra, Indonesia", Austrian Journal of South-East Asian Studies, 2014.

Carling, Joan, "Cordirella Peoples Alliances", UN Working Group on Indigenous Population, Jenewa, Swiss, 27 Juli 2001.

Duncan, Christopher R, "Mixed Outcomes: The Impact of Regional Autonomy and Decentralization on Indigenous Ethnic Minorities in Indonesia", Development and Change, Volume 38, Issue 4, 2007.

Kompas, "Pengakuan Hak: Masyarakat Adat Menanti, Persingkatan Birokrasi", Kompas, 14 Januari.

Mongabay, "Masyarakat Adat Matteko Berjuang Mengembalikan Hutan yang Terampas", http://www.mongabay.co.id/2013/07/30/masyarakat-adatmatteko-berjuang-mengembalikan-hutan-yang-terampas/, diakses 3 Februari 
2017.

Umozurike, Oji, “Human Rights and Development”, UNESCO, 1998.

Sengupta, Arjun, "Right to Development as a Human Right", Economic and Political Weekly, Juli 7, 2001, 2528.

Wieczorek-Zeul, Heidemarie, "Human Rights and Development", Environmental Policy and Law, Volume 38, Issue 5, 2008.

World Bank, "Decentralizing Indonesia: A Regional Public Expenditure Review", Overview Report, 2003.

Xanthaki, Alexandra, "Land Rights of Indigenous Peoples in South-East Asia", Melbourne Journal of International Law, Volume 4, Issue 2, 2003.

Yando Zakaria, "Menimbang-nimbang Kemaslahatan Undang-Undang Desa [Considering Village Law", https://independent.academia.edu/YandoZakaria, diakses 13 April 2014.

\section{Dokumen Hukum}

Undang-Undang Dasar 1945.

Undang-Undang Nomor 5 Tahun 1967 tentang Kehutanan.

Undang-Undang Nomor 5 Tahun 1979 tentang Desa.

Undang-Undang Nomor 41 Tahun 1999 tentang Kehutanan.

Undang-Undang Nomor 4 Tahun 2009 tentang Pertambangan Mineral dan Batubara.

Undang-Undang Nomor 2 Tahun 2012 tentang Pengadaan Tanah bagi Pembangunan untuk Kepentingan Umum.

Undang-Undang Nomor 18 Tahun 2013 tentang Pencegahan dan Pemberantasan Kerusakan Hutan.

Undang-Undang Nomor 6 Tahun 2014 tentang Desa.

Undang-Undang Nomor 39 Tahun 2014 tentang Perkebunan.

Peraturan Pemerintah Nomor 24 Tahun 1997 tentang Pendaftaran Tanah.

Peraturan Pemerintah Nomor 23 Tahun 2010 tentang Pelaksanaan Kegiatan Pertambangan Mineral dan Batubara.

Keputusan Presiden Nomor 55 Tahun 1993 tentang Pengadaan Tanah bagi Pelaksanaan Pembangunan untuk Kepentingan Umum.

Peraturan Menteri Dalam Negeri Nomor 52 Tahun 2014 tentang Pedoman Pengakuan dan Perlindungan Masyarakat Hukum Adat.

Peraturan Menteri Agraria dan Tata Ruang/Kepala Badan Pertanahan Nasional Nomor 10 Tahun 2016 tentang Tata Cata Penetapan Hak Komunal atas Tanah Masyarakat Hukum Adat dan Masyarakat yang Berada dalam Kawasan Tertentu. Committee on the Elimination of Racial Discrimination, "General Recommendation XXIII: Indigenous Peoples", 18 Agustus 1997. 
Human Right Council, "CCPR General Comment 23: The Rights of Minorities" (8 April 1994).

International Labor Organization Convention concerning the Protection and Integration of Indigenous and other Tribal and Semi-Tribal Populations in Independent Contries, 1957 (ILO Convention No. 107).

International Labor Organization Convention concerning Indigenous and Tribal Peoples in Independent Countries, 1989 (ILO Convention No. 169).

The Charter of the United Nations.

The Declaration on The Right to Development.

The Universal Declaration of Human Rights.

The Second United Nations World Conference on Human Rights.

United Nations Declaration on the Rights of Indigenous Peoples, GA Res 61/295, UN GAOR, $61^{\text {st }}$ sess, $107^{\text {th }}$ plen mtg. Supp No 49, UN Document A/RES/61/295 (13 September 2007).

United Nations International Covenant on Civil and Political Rights 1966.

United Nations Educational, Scientific, and Cultural Organization Convention concerning the Protection of the World Cultural and Natural Heritage 1972.

Putusan Mahkamah Konstitusi Nomor 45/PUU-IV/2011 tentang Pengujian UndangUndang Nomor 41 Tahun 1999 tentang Kehutanan, putusan diucapkan dalam sidang Pleno Mahkamah Konstitusi yang terbuka untuk umum pada hari Selasa, 21 Februari 2012.

Putusan Mahkamah Konstitusi Nomor 35/PUU-XII/2012 Tahun 2012 terkait Pengujian Undang-Undang Nomor 41 Tahun 1999 tentang Kehutanan terhadap Undang-Undang Dasar 1945, putusan diucapkan dalam sidang Pleno Mahkamah Konstitusi yang terbuka untuk umum pada hari Kamis, 16 Mei 2013.

Putusan Mahkamah Konstitusi Nomor 50/PUU-X/2012 tentang Permohonan Pengujian Undang-Undang Nomor 2 Tahun 2012 tentang Pengadaan Tanah Bagi Pembangunan untuk Kepentingan Umum terhadap Undang-Undang Dasar 1945, putusan diucapkan dalam sidang Pleno Mahkamah Konstitusi yang terbuka untuk umum pada hari Rabu, 13 Februari 2013.

Human Right Council, Lubicon Lake Band v Canada, Communication No 167/1984, UN Document CCPR/C/38/D/167/1984 (1990).

,Lovelace v Canada, Communication No 24/1997, UN Document CCPR/C/13/D/24/1997 (30 Juli 1981), Hopu v France, HRC, Communication No 549/1993, UN Document CCPR/C/60/D/549/1993/Rev.1 (29 Juli 1997). 